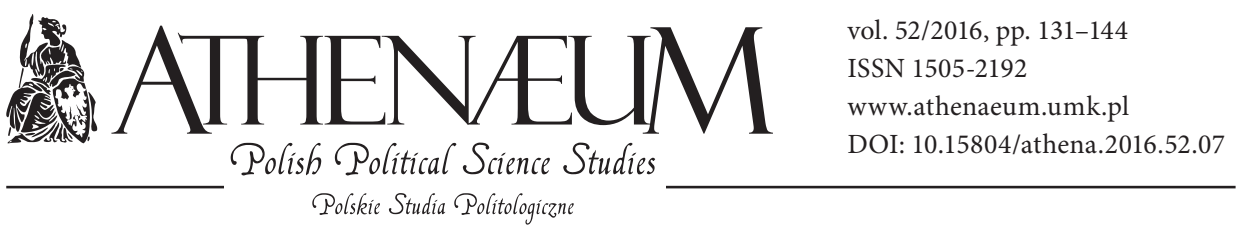

\title{
OPTIMAL MONETARY POLICY WITH A COST CHANNEL
}

\author{
OPTYMALNA POLITYKA PIENIĘŻNA W SYTUACII ISTNIENIA \\ KANAŁU KOSZTÓW
}

Magdalena Redo*

\begin{abstract}
More and more research confirms the influence of monetary policy over supply through the costs level (especially in reference to the working capital costs) and over the marginal costs of a given enterprise which influences their pricing policy and manufacturing decisions. Thus, it has become a necessity in the monetary policy's effectiveness to take into account cost channels of transmitting monetary policy into economy, along with identification of factors determining its effectiveness. It may point out to the stronger reaction of the central bank in order to repress costly inflationary pressure; it may as well point out to a lower interest increase in order to not increase inflation expectations. It depends on the specificity of a given economy - to be precise, the role of a cost channel and market expectations, as well as the strength of an interest rate channel. The central bank should analyze the effects of its actions in order to neutralize negative consequences and increase its effectiveness. Thus, when it comes to the cost channel, it comes as
\end{abstract}

\begin{abstract}
Coraz większa ilość badań dowodzi wpływu polityki pieniężnej na podażową stronę gospodarki poprzez oddziaływanie na poziom kosztów finansowych (w szczególności kosztu kapitału pracującego), a tym samym na wysokość kosztów marginalnych przedsiębiorstwa, co wpływa na ich politykę cenową i decyzje o wielkości produkcji. Z tego względu kluczowe dla skuteczności polityki pieniężnej jest uwzględnienie kanału kosztów w transmisji polityki pieniężnej do gospodarki wraz z identyfikacją czynników determinujących jego drożność. Może ono wskazywać na silniejszą reakcję banku centralnego, by tłumić kosztową presję inflacyjną, albo na słabszy wzrost oprocentowania, by nie wzmagać oczekiwań inflacyjnych. Zależy to od specyfiki danej gospodarki - od roli, jaką odgrywają w niej kanał kosztów oraz oczekiwania rynkowe, ale także od siły działania kanału stopy procentowej. Bank centralny powinien więc zgłębiać skutki swych działań, by neutralizować ich negatywne efekty, a tym samym podnieść swą skuteczność. Dlatego też w sytuacji
\end{abstract}

\footnotetext{
* Nicolaus Copernicus University, Faculty of Political Sciences and International Studies.
} 
more effective for the central bank to focus on the inflation goal and to base the monetary policy on the aim of achieving this goal. To strengthen the effectiveness and credibility, it is necessary to create a realistic strategy should economical crisis occur.

Keywords: monetary policy, the transmission mechanism of monetary policy, channels of monetary transmission, cost channel, the cost of working capital działania kanału kosztów właściwe wydaje się skupienie banku centralnego na celu inflacyjnym i oparcie polityki pieniężnej na zobowiązaniu do jego osiągnięcia. Dla wzmocnienia skuteczności i wiarygodności niezbędne jest również wypracowanie realistycznej strategii działania na wypadek załamania się płynności w gospodarce.

Słowa kluczowe: polityka pieniężna, mechanizm transmisji polityki pieniężnej, kanały transmisji pieniężnej, kanał kosztów, koszt kapitału pracującego

\section{INTRODUCTION}

An extensive body of literature confirming empirical activity of a cost channel and its varying strength in different economies, trade types or time indicates that ignoring its presence (and differences in its potency) distorts a true image of the mechanism of transmitting monetary policy into economy; thus, it distorts the quality of recommendations for optimization of the central bank's policy (Michaelis, Palek, 2014). More and more research confirms the influence of monetary policy over supply through the costs level (especially in reference to the working capital costs) and over the marginal costs of a given enterprise which influences their pricing policy and manufacturing decisions (i.a., Barth, Ramey, 2000; Gaiotti, Secchi, 2004; Dedola, Lippi, 2005; Ravenna, Walsh, 2006; Henzel, Hülsewig, Mayer, Wollmershäuser, 2007; Hülsewig, Mayer, Wollmershäuser, 2009; Della Chang, Jansen, 2014; Tillmann, 2006; Tillmann, 2008; Chowdhury, Hoffmann, Schabert, 2006; Christiano, Eichenbaum, Evans, 2005; Silva, Paes, 2015). Tightening of monetary policy may contribute to the inflation increase (price puz$z l e$ ) and production reduction. Thus, the central bank should take into account the presence of the cost channel and adjust its reaction and instruments to the scope and strength of its activity. In order to do that, it is necessary to have a continuous monitoring of changes of this mechanism's importance on transmitting impulses of monetary policy into economy alongside undergoing changes in the national financial market, international financial markets, the financial flow in the financial and capital market, the quantity, cost and availability of capital in the internal and external markets, the structure, strength and the financial-capital situation of the banking sector, the tendency of banks to give loans for changes of interest 
rates in the central bank, the course of economic situation, the level of market interest and its diversity when it comes to strength, speed, completeness and the asymmetry of the pass-through effect of monetary policy in reference to internal credit market, the financial-capital condition of enterprises and their dependency on external financial sources, the need of working capital, dependency on bank credit, availability of alternative financing sources (especially short-term sources), specificity of monetary policy of enterprises, their prices and asymmetry of prices, the exchange-rate regime and its stability, legal regulations and means used by economic policy which may strengthen or weaken the activity of the cost channel and monetary policy and all other factors that may increase (or decrease) difficulties when it comes to availability of financing sources with, at the same time, causing the strength of monetary policy impulses to increase or decrease. Due to complexity of economic mechanisms, it is impossible to list all factors determining the strength of the cost channel. It is certain that further research will provide more information on factors contributing to the importance of a cost channel. The art is to correctly evaluate the importance of some of the factors in the activity of the cost channel and the negative effect of the other factors on the effectiveness of the central bank in terms of economic changes, financial markets, regulations or other means of economic policy. The last step is to take that into consideration while defining monetary policy.

The main aim of the present work is to create a set of recommendations for the central bank that will optimize monetary policy in terms of the cost channel with, at the same time, increasing the effectiveness of monetary policy in strengthening economic stability. Using the induction method, an evaluation was made. The evaluation concerned results of international econometric studies and the current state of knowledge in terms of influence of the cost channel in transmitting monetary policy into economy over effectiveness of monetary policy of the central bank. The evaluation also pointed out certain implications which are generated by this mechanism in terms of optimizing monetary policy. Polish scientific literature lacks research analyzing the activity of the cost channel, while the current position of the banking sector and dependency of enterprises on a bank credit seem to predestine towards the activity of the cost channel in Poland (Redo, 2016b).

The analysis of study results on the cost mechanism in transmitting monetary policy into economy indicates that becoming familiar with the specificity of its action and factors determining its effectiveness is essential for the effectiveness of monetary policy. It may confirm the stronger reaction of the central bank in 
order to suppress the inflation pressure when it comes to cost; it also may suggest lower increase of interest rates, in order to suppress inflation expectations. It all depends on the specificity of a given economy - the role of the cost channel and market expectations, as well as the strength of an interest-rate channel. The central bank should analyze the effects of its actions in order to neutralize negative effects and increase its effectiveness. In the context of the cost channel, it occurs as necessary to focus on the inflation goal and to base the monetary policy on achieving this goal. In order to strengthen the effectiveness and credibility, it is also necessary to create a realistic strategy should an economic crisis take place.

\section{MONETARY POLICY SHOULD REACT STRONGER}

As the activity of the cost channel weakens the anti-inflation activity of monetary policy, it may be argued that the reaction of the central bank towards inflation should be stronger (Michaelis, Palek, 2014). This opinion is supported by Castelnuovo, Surico (2006), who refer to the role of inflation expectations in shaping inflation and the necessity of their effective stabilization because, as they suggest, those may be in part responsible for the price increase after tightening of monetary policy (price puzzle). Over the decades, the growing importance of inflation expectations in the construction of monetary policy may be identified in many countries in the growing dependency between the strength of the central bank's reaction and the level of inflation in Taylor's rule (monetary policy in the USA reacts nowadays much stronger towards inflation expectations than a few decades ago; Bernanke, 2004). As Bernanke (2004) underlines, a reaction of monetary policy towards inflation that is not enough aggressive may in fact increase inflation expectations and speed the inflation, which is consistent with the results obtained by Castelnuovo, Surico (2006). Castelnuovo and Surico indicated that the price puzzle phenomenon is present in the times of decreased reaction of central banks on inflation (for example, before Volcker's presidency in the USA - until 1979, or in Great Britain before introducing the inflation strategy in the Bank of England in 1992). Another important factor for a stronger reaction of the central bank is mentioned by Kobayashi (2008). Kobayashi points out that, in the case of an incomplete pass-through effect, monetary policy should react stronger to changes occurring on the average level of credit interests, as the average is not representative and a weaker reaction of the central bank will only deepen discrepancies within the credit cost level between enterprises which 
will consequently lead to the growth of disproportion in the marginal costs of enterprises and to overpricing. It is especially related to the economies in which enterprises establish their own prices partly on the basis of competition, as visible in the case of most Eurozone countries (Fabiani et al., 2005). However, as Michaelis, Palek (2014) indicated, the higher the diversity when it comes to strength of the cost channel between economies of the monetary union, the weaker the increase of aggression levels of monetary policy. The higher diversity in the strength of the cost channel between economies of the monetary union leads to lower effectiveness of the central bank in stabilizing inflation and, consequently, to lesser number of advantages of being in the Eurozone, especially for countries with the strongest and the weakest cost channel activity.

Finally, it has to be noted that significant reduction of interest rates at the time of the financial crisis of 2008 greatly weakened the possibility of impacting economy by the use of this tool. Hence, Čihák, Harjes, Stavrev (2009), who indicated that the pass-through effect within the Eurozone functions weaker after the crisis, pointed out that monetary policy should act stronger nowadays in order to achieve the same effect as the one before the crisis. These conclusions are consistent with the results of Apergis, Cooray (2015), who point out that limitation with zero interest rates contributed to deactivation of the pass-through effect also in the USA and Great Britain.

\section{MONETARY POLICY SHOULD HAVE A SLOWER AND WEAKER REACTION}

On the other hand, one must remember that more aggressive reaction of the central bank (greater increase of interest rates) may cause higher inflation expectations and encourage price increase. Thus, as Brückner, Schabert (2003) and Christiano, Trabandt, Walentin (2010) point out, when it comes to cost channel activity, one cannot rely exclusively on the Taylor's rule as it may bring opposite effects to those that were expected. It is especially related to central banks that are focused exclusively on inflation and that are associated with bigger risk of making decisions. It is wise to agree with Smith (2015) who points out that not only is there lower but also upper limit when it comes to the strength of reaction of the central bank towards the inflation growth in order to eliminate the effect of self-fulfilling inflation expectations and anchoring them on an appropriate level. Of course, the upper limit of reaction of monetary policy towards the 
inflation increase, according to the Taylor's rule, should be adjusted to the current activity of the cost channel in a given economy, which means taking into consideration not only quantity and importance of enterprises that are greatly dependant on external financial sources, but also current situation of the credit market which determines availability and credit costs, which means the power of the cost mechanism in transmitting monetary policy on price levels (Christiano, Trabandt, Walentin, 2010; Surico, 2008).

Tillmann (2009) also points to an important argument against excessive aggressive reaction of the central bank. It indicates that because the studies show strong differences between the activity of the cost channel not only in different countries, but also in time and a growing number of factors strengthening or weakening its effectiveness, the central bank is not able to foresee the scale of tightening (or easing) of credit conditions as a result of changes in interest rates. The uncertainty of the power of the cost channel reflects the uncertainty related to the nature of financial markets and their role in transmitting monetary policy into the supply part of economy. Tillmann (2009) suggests that in the context of uncertainty in terms of power of the cost channel, monetary policy should estimate its power and pursue a less aggressive monetary policy based on the min-max rule (minimizing the risk of the worst scenario) and act according to the Brainard's cautious politics rule (1967). Tillmann (2009) showed that the higher the uncertainty when it comes to the cost channel activity, the reaction of interest rates of the central bank towards inflation should be weaker, especially when it comes to tensions on financial markets which strengthen the activity of the cost channel. Aysun, Brady, Honig (2013) are also against the strong reaction of monetary policy. They stated that financial tensions multiply in the times of crisis and they strengthen monetary policy's power. Thus, Gaiotti, Secchi (2004) insist that the cost channel should be taken into account while creating optimum monetary policy as it is responsible for short-term price increase resulting from tightening of monetary policy; following that, the central bank should gradually increase interest rates. Westermeier (2010) supports the idea of defining interest rates on a level lower than then optimum one due to the activity of the cost channel. Also Ravenna, Walsh (2006) suggest that monetary policy should gradually stabilize inflation. Finally, it is worth to mention Tillmann's (2007) theory that the activity of the cost channel neutralizes the argument mentioned by, for example, Giannoni (2007) or Onatski, Stock (2002), in which, with relation to uncertainty of econometric modeling, monetary policy should react stronger to shock. Tillmann (2007) indicates that the presence of the cost channel reduces 
effectiveness of monetary policy in confrontation with inflation; thus, there is no reason for monetary policy to react stronger to shocks. Therefore, he confirms Brainard's (1967) opinion that monetary policy should not be aggressive as it may excessively strengthen the cost channel activity and, as a result, cause a too weak reaction of the central bank towards inflation.

\section{CENTRAL BANK SHOULD RECOGNIZE THE COST CHANNEL ACTIVITIY TO NEUTRALIZE NEGATIVE EFFECTS}

The presence of the cost channel increases inflation fluctuations, because monetary policy focuses more on stabilizing the scope of production. On the other hand, when the central bank is focused mainly on stabilizing inflation, the cost channel strengthens fluctuations of the demand gap (strengthens trade-off between the inflation level and the scope of production - Kilponen, Milne, 2007; Mallik, Chowdhury, 2001). Thus, optimum monetary policy should neutralize potential negative effects (Ravenna, Walsh, 2006); it is necessary to get to know the mechanism of the cost channel activity in a given economy and to take into account its influence on the effects of the use of monetary policy's tools. It is necessary to identify the widest possible range of factors strengthening and weakening the activity of the cost channel to monitor potential occurrences that may disrupt its previous effectiveness. It is a necessary condition in order to maintaining effective realization of monetary policy (not only due to the price puzzle phenomenon caused by the cost channel). It also implies correct defining of the interest level of the central bank - the level which ensures creating a proper inflation path and/ or economic growth, which results in economic stabilization. Finally, it is worth mentioning that Surico (2008) suggested that monetary policy, in the case of the cost channel activity, should focus exclusively on stabilizing inflation and limiting the importance of demand gap fluctuations in the reaction function.

\section{CENTRAL BANK SHOULD CONDUCT ITS MONETARY POLICY IN}

\section{A LESS TRANSPARENT MANNER}

It is worth to note here the study results of Dai, Zhang (2013), who indicated that in the case of activity of the cost channel, decreased transparency of monetary policy decreases the inflation fluctuations and increases production change- 
ability; it suggests that, when the main goal of the monetary policy is to stabilize price levels (or inflation) and the society devotes less attention to stabilization of production, the monetary policy should not be too transparent. This thesis, however, requires further analysis.

\section{CENTRAL BANK SHOULD BASE MONETARY POLICY ON OBLIGATIONS}

As the strong cost channel activity limits effectiveness of monetary policy and may deepen economic instability, monetary policy should be, according to Llosa, Tuesta (2009), based on the obligation to define optimum monetary policy in the case of the cost channel activity. As a result, the effects coming from the cost channel activity would be less severe. They point out that taking into consideration the cost channel while modeling optimum monetary policy greatly changes previous conclusions. In the situation when the cost channel is present, discretional monetary policy or the one based on Taylor's rule may bring counter results (deepen instability). These conclusions are confirmed by Michaelis, Palek (2014), who also indicate that in the context of the cost channel activity, the most effective monetary policy is the one that is based on obligations. They indicated that monetary policy based on obligations is more effective than the one based on the Taylor's rule, which, consequently, is more effective than the strategy of direct inflation goal and the discretional monetary policy. The advantages of turning towards monetary policy based on obligations are significantly greater when the cost channel activity increases as well as the diversity in its power between economies of currency union. The superiority of monetary policy based on obligation was also identified by Bask, Proaño (2012).

The above mentioned conclusions are consistent with the study of Demirel (2013), who indicated the importance of obligations of the central bank is significantly higher than it was expected, especially when it comes to the economies in which the cost channel is active. He indicated a strong positive relationship between the activity of the cost channel and benefits from obligations of the central banks; he also indicated that omitting the cost channel activity causes underestimation of benefits of the future character of monetary policy that come from the central bank's obligation. He indicated that not taking into consideration the cost channel in the US economy while estimating benefits coming from the central bank results in underestimation of the quarterly inflation of 0.48 per- 
centage point. When interest changes greatly influence the level of marginal costs, monetary policy based on obligations allows to create inflation expectations in a more effective manner, in order to balance between inflation stabilization and production. Benefits coming from obligations of monetary policy result from higher effectiveness of the central bank in steering market expectations and from reaching stability despite stronger trade-off effect between stabilizing inflation and production. The importance of obligations in the context of maintaining low inflation (low inflation target) increases along with the power of the cost channel activity. This statement is supported by Lam (2010), who indicated the significant growth of importance of credible obligations of the central bank for sustaining low inflation in the event of strong activity of the cost channel.

\section{IT IS CRUCIAL TO WORK ON DEVELOPMENT AND QUALITY OF ECONOMETRIC MODELING}

Despite significant amount of knowledge on the mechanism of the cost channel, further study is needed in order to recognize determinants of power and changes in its effectiveness, which will further allow for greater effectiveness of monetary policy. Thus, the central bank should continuously develop its econometric models, open its assumptions to possible changes, take into account the amount of economic interdependencies, assign a bigger role to the banking sector - especially in economies with the banking financial model (Tamborini, 2009; Kopecky, Van Hoose, 2012; Karagiannis, Panagopoulos, Vlamis, 2010; Silva, Paes, 2015) - by testing the activity of channel cost in isolation and in relation with other channels present in the monetary policy transmission in order to correctly reflect economic reality, to evaluate the cost channel's activity in a given country, to identify main determinants of its effectiveness and to define effective monetary policy (Malikane, 2012).

\section{THE CENTRAL BANK SHOULD CREATE A STRATEGY IN CASE OF LIQUIDITY BREAKDOWN}

This information is crucial not only to ease the negative effects of the cost channel activity and to manage effective monetary policy despite its activity, but also to correctly identify potential disruptions in the channel's effectiveness which 
may threaten the economy's stability limit abilities of monetary policy as well as the entire economic policy. Thus, one shall agree with Karagiannis, Panagopoulos, Vlamis (2010) who point out to the necessity of creating a strategy for the central bank in case of radical decrease of liquidity in the financial sector and, consequently, decrease of the pass-through effect (as it took place during the crisis of 2008 in the USA and in the Eurozone); such strategy should be created in order to restore the effectiveness of the mechanism of monetary policy transmission, effectiveness of which conditions the central bank's ability to ease the effects of the liquidity crisis. Fast reaction, proper action and correct instruments (to reduce liquidity problem within the highest number of enterprises possible) are key factors; however, it is necessary to also think about the golden mean principle. These actions should not lead to excessive dependency of the market on the central bank or increase the issue of moral hazard. It is necessary to re-regulate financial markets to prevent excessive risk-taking (Borio, Zhu, 2008; Redo, 2013; Redo, 2015), and work on strengthening of cooperation and communication between central banks and between the central bank and the market - to increase the effectiveness and stability of those markets. Finally, in case of liquidity crisis, cooperation between monetary and fiscal policy is essential to create an effective policy-mix which will restore economy to the balanced economic growth (with low inflation) (Redo, 2016a).

\section{CONCLUSIONS}

The cost channel activity decreases the central bank's effectiveness in stabilizing inflation; thus, as some economists argue, monetary policy should be more aggressive in order to stabilize market expectations more effectively. It is especially related to the economies with incomplete pass-through effect when it comes to interest rates; that generates high diversity when it comes to capital costs between enterprises. Additionally, another argument may be found in significant decrease in activity (or even deactivation) of the interest rates channel in monetary policy transmission due to extremely low interest rates stemming from the crisis of 2008. Opponents of this solution argue that, in order to eliminate the effect of self-made inflation expectations and set them on a desired level, it is necessary to have a weaker reaction of the central bank, especially in the situation of insufficient knowledge of the cost channel mechanism and uncertainty of credit conditions stemming from changes in interest rates of the 
central bank. It is especially related to periods of tension on financial markets, which strengthen the activity of the cost channel. Considering the above counter arguments, it is necessary to proceed with research which will help in exploring the cost mechanism in monetary policy transmission, exploring its changeability through time to predict effects of the decisions of the central bank, neutralizing its potential negative effects and increasing the effectiveness of the monetary policy, identifying factors contributing to its effectiveness in a given economy and factors that may cause disruption in its activity. In order to achieve that, econometric models which support decision-making processes of the central bank need to be developed. As the cost channel activity increases the trade-off phenomenon between inflation and production, it occurs as necessary to have the monetary policy focus exclusively on the inflation target and to base it on the condition of maintaining the established level of inflation. Then, inflation expectations can be created in a much more effective way and economic stability can be built despite disruptions caused by the cost channel and uncertainty of its functioning. Development of a strategy in case of liquidity breakdown, taking into account specific features of a given economy, activity of the cost channel as well as amount and importance of enterprises depending on external financing, seems to be a key factor for effectiveness of the central bank in creating market expectations and building stability.

The above will help in preventing a radical strengthening of the cost channel in the context of new economic shocks. To achieve that, it is necessary to explore the cost channel mechanism in a given economy in order to estimate if, due to the cost channel activity and weaker effectiveness of the interest rates channel, a stronger reaction of the central bank is needed or, due to higher sensitivity of market expectations towards interest rates, it is necessary to have a weaker reaction of the central bank to not only prevent self-fulfilling inflation expectations, but also to maintain the activity of the cost channel in the context of economic tensions which additionally increase its effectiveness.

Understanding the role of the cost channel is essential to maintain stability of enterprises, their development, creating workplaces - socio-economic development. Although it corresponds to all economies, especially those with lower wealth and credibility level (and also limited capital availability) should recognize the importance of improving effectiveness of using means of economic policy which enable development and stability. Good knowledge of the cost channel activity is also significant in terms of Poland's potential entering the Eurozone and submitting to monetary policy of the European Central Bank, which defines 
lower level of interest rates and is characterized by weaker and varied power of reaction when contrasted with NBP (National Bank of Poland - translator's annotation). Adoption of the euro currency will undoubtedly change the pass-through effect on interest rates and the cost channel in Poland. The above mentioned aspects shall be taken into consideration while conducting an analysis of advantages and disadvantages of adopting euro by Poland.

\section{REFERENCES:}

Apergis, N., Cooray, A. (2015). Asymmetric Interest Rate Pass-Through in the U.S., the U.K. and Australia: New Evidence from Selected Individual Banks. Journal of Macroeconomics, 45, 155-172. DOI:10.1016/j.jmacro.2015.04.010.

Aysun, U., Brady, R., Honig, A. (2013). Financial Frictions and the Strength of Monetary Transmission. Journal of International Money and Finance, 32, 1097-1119. DOI:10.1016/j.jimonfin.2012.09.003.

Barth III, M.J., Ramey, V.A. (2000). The Cost Channel of Monetary Transmission. NBER Working Paper No. 7675.

Bask, M., Proaño, C.R. (2012). Optimal Monetary Policy Under Learning in a New Keynesian Model with Cost Channel and Inflation Inertia. Department of Economics Working Paper No. 7, 1-25.

Bernanke, B.S. (2004). The Great Moderation, Remarks by Governor Ben S. Bernanke at the Meetings of the Eastern Economic Association. Washington: DC.

Borio, C., Zhu, H. (2008). Capital Regulation, Risk-taking and Monetary Policy: A Missing Link in the Transmission Mechanism? BIS Working Paper, No 268.

Brainard, W. (1967). Uncertainty and the Effectiveness of Policy. The American Economic Review, 57 (2), 411-442.

Brückner, M., Schabert, A. (2003). Supply-side Effects of Monetary Policy and Equilibrium Multiplicity. Economics Letters, 79 (2), 205-211. DOI:10.1016/S01651765(02)00328-2.

Castelnuovo, E., Surico, P. (2006). The Price Puzzle: Fact or Artifact? Bank of England Working Paper No. 288. DOI: 10.2139/ssrn.878089.

Chowdhury, I., Hoffmann, M., Schabert, A. (2006). Inflation Dynamics and the Cost Channel of Monetary Transmission. European Economic Review, 50 (4), 995-1016. DOI:10.1016/j.euroecorev.2005.01.007.

Christiano, L.J., Eichenbaum, M., Evans, C.L. (2005). Nominal Rigidities and the Dynamic Effects of a Shock to Monetary Policy. Journal of Political Economy, 113 (1), 1-45.

Christiano, L.J., Trabandt, M., Walentin, K. (2010). DSGE Models for Monetary Policy Analysis. NBER Working Paper No. 16074.

Čihák, M., Harjes, T., Stavrev, E. (2009). Euro Area Monetary Policy in Uncharted Waters. IMF Working Paper No. 185, 1-34. 
Dai, M., Zhang, Q. (2013). Central Bank Transparency with the Cost Channel. BETA Document de Travail No. 06.

Dedola, L., Lippi, F. (2005). The Monetary Transmission Mechanism: Evidence from the Industries of Five OECD Countries. European Economic Review, 49 (6), 1543-1569. DOI:10.1016/j.euroecorev.2003.11.006.

Della Chang, J.C., Jansen, D.W. (2014). Inflation Dynamics and the Cost Channel: The Small Open Economy Case. Annals of Economics and Finance, 15(2), 325-341.

Demirel, U.D. (2013). Gains from Commitment in Monetary Policy: Implications of the Cost Channel. Journal of Macroeconomics, 38 (B), 218-226.

Fabiani, S., Druant, M., Hernando, I., Kwapil, C., Landau, B., Loupias, C., Martins, F., Mathä, T.Y., Sabbatini, R., Stahl, H., Stokman, A. (2005). The Pricing Behavior of Firms in the Euro Area: New Survey Evidence. European Central Bank Working Paper No. 535.

Gaiotti, E., Secchi, A. (2004). Is There a Cost Channel of Monetary Policy Transmission? An Investigation into the Pricing Behavior of 2,000 Firms. Temi di discussione del Servizio Studi No 525.

Giannoni, M.P. (2007). Robust Optimal Monetary Policy in a Forward-looking Model with Parameter and Shock Uncertainty. Journal of Applied Econometrics, 22 (1), 179-213. DOI: 10.1002/jae.934.

Henzel, S., Hülsewig, O., Mayer, E., Wollmershäuser, T. (2007). The Price Puzzle Revisited: Can the Cost Channel Explain a Rise in Inflation After a Monetary Policy Shock? CESifo Working Paper Series No. 2039.

Hülsewig, O., Mayer, E., Wollmershäuser, T. (2009). Bank Behavior, Incomplete Interest Rate Pass-Through, and the Cost Channel of Monetary Policy Transmission. Economic Modelling, 26 (6), 1310-1327. DOI:10.1016/j.econmod.2009.06.007.

Karagiannis, S., Panagopoulos, Y., Vlamis, P. (2010). Interest Rate Pass-Through in Europe and the US: Monetary Policy After the Financial Crisis. Journal of Policy Modeling, 32 (3), 323-338. DOI:10.1016/j.jpolmod.2010.02.006.

Kilponen, J., Milne, A. (2007). The Lending Channel Under Optimal Choice of Monetary Policy. Bank of Finland Research Discussion Paper No. 33.

Kobayashi, T. (2008). Incomplete Interest Rate Pass-Through and Optimal Monetary Policy. International Journal of Central Banking, 4 (3), 77-118.

Kopecky, K.J., Van Hoose, D.D. (2012). Imperfect Competition in Bank Retail Markets, Deposit and Loan Rate Dynamics, and Incomplete Pass Through. Journal of Money, Credit and Banking, 44 (6), 1185-1205. DOI: 10.1111/j.1538-4616.2012.00527.x.

Lam, J.P. (2010). The Importance of Commitment in the New Keynesian Model. The B.E. Journal of Macroeconomics, 10 (1), 1-23.

Llosa, L.G., Tuesta, V. (2009). Learning About Monetary Policy Rules When the Cost Channel Matters. Journal of Economic Dynamics and Control, 33 (11), 1880-1896. DOI:10.1016/j.jedc.2009.05.001.

Mallik, G., Chowdhury, A. (2001). Inflation and Economic Growth: Evidence from Four South Asian Countries. Asia-Pacific Development Journal, 8 (1), 123-135.

Malikane, C. (2012). Inflation Dynamics and the Cost Channel in Emerging Markets. MPRA. Munich Personal RePEc Archive Paper No. 42688, December. 
Michaelis, J., Palek, J. (2014). Optimal Monetary Policy in a Currency Union: Implications of a Country-specific Cost Channel. Joint Discussion Paper Series in Economics by the Universities of MAGKS No. 44.

Onatski, A., Stock, J.H. (2002). Robust Monetary Policy Under Model Uncertainty in a Small Model of the US Economy. Macroeconomic Dynamics, 6 (1), 85-110.

Ravenna, F., Walsh, C. (2006). Optimal Monetary Policy with the Cost Channel. Journal of Monetary Economics, 53 (2), 199-216. DOI:10.1016/j.jmoneco.2005.01.004.

Redo, M. (2013). The Growing Importance of the Risk-taking Channel in the Process of Transmitting Monetary Policy. Torun International Studies, 1 (6), 13-22. DOI: http:// dx.doi.org/10.12775/TIS.2013.002.

Redo, M. (2015). The Importance of Prudential Regulations in the Process of Transmitting Monetary Policy to Economy. Copernican Journal of Finance \& Accounting, 4 (2), 145-158. DOI: http://dx.doi.org/10.12775/CJFA.2015.021.

Redo, M. (2016a). Wzrost znaczenia kanału oczekiwań rynkowych w procesie transmisji polityki pieniężnej do gospodarki w sytuacji coraz niższych stóp procentowych (in press).

Redo, M. (2016b). Kanał kosztów w mechanizmie transmisji polityki pieniężnej do gospodarki - ocena wpływu poziomu stóp procentowych NBP na wielkość kapitału pracującego przedsiębiorstw w Polsce w latach 2005-2015 (in press).

Silva, I.É.M., Paes, N.L. (2015). Evidences of Incomplete Interest Rate Pass-Through, Directed Credit and Cost Channel of Monetary Policy in Brazil. Área 4 - Macroeconomia, Economia Monetária e Finanças.

Smith, A.L. (2015). When Does the Cost Channel Pose a Challenge to Inflation Targeting Central Banks? The Federal Reserve Bank of Kansas City Research Working Paper No. 15-06.

Surico, P. (2008). The Cost Channel of Monetary Policy and Indeterminacy. Macroeconomic Dynamics, 12 (5), 724-735. DOI: http://dx.doi.org/10.1017/S1365100508070338.

Tamborini, R. (2009). The "Credit-Cost Channel" of Monetary Policy. A theoretical assessment. Economics: The Open-Access, Open-Assessment E-Journal, 3 (2009-13), 1-23. DOI: http://dx.doi.org/10.5018/economics-ejournal.ja.2009-13.

Tillmann, P. (2006). Does the Cost Channel of Monetary Transmission Explain Inflation Dynamics. University of Bonn (unpublished, May).

Tillmann, P. (2007). Robust Monetary Policy with the Cost Channel. European Economy Economic Paper, 278.

Tillmann, P. (2008). Do Interest Rate Drive Inflation Dynamics? An Analysis of the Cost Channel of Monetary Transmission. Journal of Economic Dynamics and Control, 32 (i), 2723-2744. DOI:10.1016/j.jedc.2007.10.005.

Tillmann, P. (2009). Optimal Monetary Policy with an Uncertain Cost Channel. Journal of Money, Credit and Banking, 41 (5), 885-906. DOI: 10.1111/j.1538-4616.2009.00237.x. Westermeier, A. (2011). The Cost Channel of Monetary Policy Transmission. South East European Journal of Economics and Business, 5 (1), 19-23. DOI: 10.2478/v10033010-0002-7. 